\title{
A PERSPECTIVE FROM THE MAYA REGION: CLOSING THOUGHTS ON SLOAD AND SUGIYAMA, SUGIYAMA, AND SARABIA G.
}

\author{
Geoffrey E. Braswell
}

The call to realign the absolute dates of the Teotihuacan ceramic sequence has implications for interpretation of the Late Formative to Early Classic throughout Mesoamerica; ceramics, radiocarbon, and hieroglyphic dates from the Maya region must be considered when evaluating this proposal.

La llamada para realinear las fechas absolutas de la secuencia cerámica de Teotihuacan tiene implicaciones para la interpretación de los sitios del formativo tardío a clásico temprano a lo largo de Mesoamérica. Como parte de la evaluación de esta propuesta, se deben considerar las fechas jeroglíficas, de cerámica, y de radiocarbono de la región maya.

\section{$\mathrm{T}$}

wo recent articles (Sload 2015; Sugiyama et al. 2013) and the resulting exchange raise important questions about the dating of Teotihuacan. I will not reinterpret other scholars' excavations or their understandings of contexts, or take a position in this fruitful debate. Instead, my purpose is to draw the attention of readers of the journal who do not work at Teotihuacan to the broader implications for the Maya region and Mesoamerica.

Chronologies are fragile structures that depend upon each other like a house of cards. Changes to the chronology of a pivotal city often have consequences for distant sites. Inomata and colleagues' (2014) proposed realignment of Middle to Late Formative Kaminaljuyu ceram- ics, for example, has considerable and contested implications for contemporary sites from Chiapas to El Salvador (see Love's and Mendelsohn's contributions in this issue). Proposed changes to the absolute chronology of the Teotihuacan sequence are even more momentous because of the central importance of that city.

Ceramics manufactured in the Maya area have been found at Teotihuacan, including Chicanel pottery mixed with Tzacualli sherds within the fill of the Sun Pyramid. Absent from the same contexts are Early Classic Maya polychromes dating to after $\mathrm{AD} 150$. It therefore seems likely that trade of Chicanel pottery occurred before the Preclassic Maya Collapse. Given the "tertiary" (sensu Sugiyama et al. 2013) nature of fill ceramics, their relevance to the debate is limited; Late Preclassic Maya ceramics from the Sun Pyramid do not support a construction date after AD 150, but the lack of Early Classic Maya pottery does not categorically rule it out.

Until the advent of radiocarbon datingand to a certain extent, into the 1980s-the absolute dates of Teotihuacan ceramic phases relied on educated guesswork and Maya hieroglyphic inscriptions. A pivotal link in a long chain of argument was Xolalpan pottery from Teotihuacan found in Mounds A and B of Kaminaljuyu (Kidder et al. 1946). Those contexts also contained Early Classic polychromes from the Maya lowlands. Similar pottery was known from Holmul (Vaillant 1935) and Uaxactun, where b'aktun 8 hieroglyphic inscriptions dated the

Geoffrey E. Braswell a Department of Anthropology, University of California, San Diego 9500 Gilman Drive, MC 0532, La Jolla, CA 92093 USA (gbraswell@ucsd.edu)

Latin American Antiquity 29(2), 2018, pp. 403-405

Copyright (C) 2018 by the Society for American Archaeology doi:10.1017/laq.2017.84 
polychromes (Ricketson and Ricketson 1937, Smith 1955). This placed the Xolalpan phase in the Maya Early Classic. In the 1960s, Xolalpan ceramics were discovered at Tikal in Early Classic contexts that also were dated by direct, stratigraphic, or iconographic association with texts containing hieroglyphic dates. Eventually, Teotihuacan imports or copies were recovered from multiple sites throughout the Maya area, sometimes with datable carbon.

The best known and most studied crossties between Teotihuacan and the Maya region date to the Early Xolalpan phase, with a strong pulse of interaction commencing with the $11 \mathrm{~Eb}$ ' 15 Mak event of AD 378 (Stuart 2000). These connections fizzled out circa AD 450, but there is evidence in the Maya area of an earlier flurry of interaction in Miccaotli or Early Tlamimilolpa times (Bove and Medrano Busto 2003:50-53; Braswell 2003:Figure 1.2; Pendergast 2003). This is smack in the middle of the period contested by Sload and Sugiyama and colleagues - that is, the late second and early third centuries AD. If Sugiyama and colleagues are correct, Mayanists may need to push forward our chronologies for the first half of the Early Classic by a century or so. In particular, complex architectural sequences at Tikal (Laporte 2003) and Kaminaljuyu (Kidder et al. 1946), ceramic phases at numerous sites (e.g., Manik 1 and 2 at Tikal, and Tzakol 1 and 2 at Uaxactun), and interpretations of the development of interaction with Teotihuacan will need to begin later and be compressed. Realigning the Miccaotli and Tlamimilolpa phases later in time implies that early and late pulses of interaction with the Maya were more or less continuous and limited to the fourth and early fifth centuries. Moreover, given that the absolute dates of Early Classic phases in the Maya area are tied to the Long Count, the realignment of the Teotihuacan ceramic chronology might entail a reevaluation of the GMT correlation.

Absolute dates from the Maya area relevant to interaction with Teotihuacan-including during Miccaotli and Tlamimilolpa times-are abundant and proceed from multiple sites rather than a single, albeit immense, structure such as the Sun Pyramid. As a Mesoamericanist who once worked at Teotihuacan, I am intrigued by the proposed redating of the Sun Pyramid. As a Mayanist, I am cautious of a set of radiocarbon assays from a distant pyramid that may require the realignment of many chronologies (some well dated, some not) from the Maya area. We must also consider much larger sets of absolute dates, as well as ceramic cross-ties, from throughout Mesoamerica that are relevant to the Late Formative to Early Classic periods.

\section{References Cited}

Bove, Frederick J., and Sonia Medrano Busto

2003 Teotihuacan, Militarism, and Pacific Guatemala. In The Maya and Teotihuacan: Reinterpreting Early Classic Interaction, edited by Geoffrey E. Braswell, pp. 45-79. University of Texas Press, Austin.

Braswell, Geoffrey E.

2003 Introduction: Reinterpreting Early Classic Interaction. In The Maya and Teotihuacan: Reinterpreting Early Classic Interaction, edited by Geoffrey E. Braswell, pp. 1-43. University of Texas Press, Austin.

Inomata, Takeshi, Raúl Ortiz, Bárbara Arroyo, and Eugenia J. Robinson

2014 Chronological Revision of Preclassic Kaminaljuyú, Guatemala: Implications for Social Processes in the Southern Maya Area. Latin American Antiquity 25:377408.

Kidder, Alfred V., Jesse D. Jennings, and Edwin M. Shook

1946 Excavations at Kaminaljuyu, Guatemala. Carnegie Institution of Washington Publication 561. Carnegie Institution of Washington, Washington, DC.

Laporte, Juan Pedro

2003 Architectural Aspects of Interaction between Tikal and Teotihuacan during the Early Classic Period. In The Maya and Teotihuacan: Reinterpreting Early Classic Interaction, edited by Geoffrey E. Braswell, pp. 199215. University of Texas Press, Austin.

Pendergast, David M.

2003 Teotihuacan at Altun Ha: Did It Make a Difference? In The Maya and Teotihuacan: Reinterpreting Early Classic Interaction, edited by Geoffrey E. Braswell, pp. 235-247. University of Texas Press, Austin.

Ricketson, Oliver G., and Edith B. Ricketson

1937 Uaxactun, Guatemala: Group E-1926-1931. Vol. 477. Carnegie Institution of Washington, Washington, DC.

Sload, Rebecca

2015 When Was the Sun Pyramid Built? Maintaining the Status Quo at Teotihuacan, Mexico. Latin American Antiquity 26:221-241.

Smith, Robert E.

1955 Ceramic Sequence at Uaxactun, Guatemala, 2 vols. Middle American Research Institute Publication 20. Tulane University, New Orleans.

Stuart, David

2000 "The Arrival of Strangers": Teotihuacan and Tollan in Classic Maya History. In Mesoamerica's Classic Heritage: From Teotihuacan to the Aztecs, edited by Davíd Carrasco, Lindsay Jones, and Scott Sessions, pp. 465-513. Colorado University Press, Niwot. 
Sugiyama, Nawa, Saburo Sugiyama, and Alejandro Sarabia $\mathrm{G}$.

2013 Inside the Sun Pyramid at Teotihuacan, Mexico: 2008-2011 Excavations and Preliminary Results. Latin American Antiquity 24:403-432.
Vaillant, George C.

1935 Chronology and Stratigraphy in the Maya Area. Maya Research 2(2):119-143. 